\title{
Socialization of UMKM Merchandise Inventory Management During the Covid 19 Pandemic in Desa Suka Makmur Kecamatan Deli Tua Kabupaten Deli Serdang
}

\author{
Harkim Simamora ${ }^{1}$, Rejekia Vaizal Simanungkalit², Maya Andriani ${ }^{3}$, \\ Bambang Sugiharto 4 \\ 1,2,3,4Sekolah Tinggi IImu Ekonomi Profesional Indonesia Medan \\ Email: 1harkimsimamora@gmail.com, 2jeckysimanungkalit1007@gmail.com, \\ 3mayaandriani6@gmail.com, 4bsugiharto@yahoo.com \\ doi https://doi.org/10.36526/gandrung.v2i2.1383
}

\begin{abstract}
The Covid pandemic has had many impacts on people's lives, one of which is the economy. The spread of the virus that requires human activities to be carried out by social distancing (maintaining social distance) and even implementing lockdown measures that have an impact on slowing economic activity (demand and supply). UMKM are one of the sectors affected by this pandemic where there is not only a decline in income, but another impact that is felt by business actors is inventory that accumulates. The implementation of this service activity has provided an understanding to UMKM actors about the importance of inventory management for UMKMs and increased the participants' ability to manage UMKM finances so that they can survive during this pandemic.
\end{abstract}

Keywords: Merchandise Inventory Management,UMKM

\section{Pendahuluan}

\section{A. Analisis Situasi}

Desa Suka Makmur merupakan salah satu desa yang ada di kecamatan Deli Tua Provinsi Sumatera Utara. Banyak usaha UMKM yang berkembangan pada saat sekarang ini mendorong khususnya masyarakat yang ada di Desa Suka Makmur untuk membentuk usaha rumah tangga berbasis UMKM.Selama Covid 19 ini melanda dunia menyebabkan para pelaku UMKM mengalami dampak yang signifikan terhadap total pendapatannya.Hal ini tentunya berdampak pada kelangsungan hidup dari UMKM.

Usaha Mikro Kecil dan Menenga atau biasa disingkat UMKM adalah kelompok usaha yang dikelola oleh orang atau suatu badan usaha tertentu yang kriterianya ditetapkan berdasarkan Undang-Undang Nomor 20 Tahun 2008.Dengan adanya peningkatan UMKM di Indonesia akan membantu perekonomian masyarakat Indonesia semakin membaik. Maka dari itu, keberadaan UMKM memiliki peran penting dalam pembangunan ekonomi nasional (Puspitosari, 2020). Alasan pertama adalah karena kinerja usaha mikro dan kecil cenderung lebih baik dalam hal menghasilkan tenaga kerja yang produktif. Kedua, sebagai bagian dari dinamikanya, usaha mikro dan kecil sering mencapai peningkatan produktivitasnya 
GANDRUNG: Jurnal Pengabdian Kepada Masyarakat ISSN: 2721-6136 (Online)

melalui investasi dan perubahan teknologi.Ketiga adalah karena sering diyakini bahwa usaha mikro dan kecil memiliki keunggulan dalam hal fleksibilitas ketimbang usaha besar (Ling, 2013).

Setiap usaha mikro, kecil dan menengah baik perusahaan dagang maupun industri memiliki persediaan. Dalam perusahaan dagang persediaannya dapat berupa persediaan barang yang akan dijual, sedangkan untuk perusahaan industri persediaan barang berupa persediaan bahan baku, persediaan bahan penolong, persediaan barang dalam proses maupun persediaan barang jadi (Istiyanto, 2017).

Pada umumnya bagi perusahaan berskala besar pengelolaan persediaan barang sudah mempunyai sistem pencatatan yang baik, bahkan sudah terkomputerisasi dan bisa setiap saat dilakukan stock opname untuk jumlah persediaan yang tersisa. Beda halnya bagi perusahaan berskala mikro dan kecil, bisa dilihat dari segi tempat usaha yang sederhana, pencatatan yang tidak beraturan antara persediaan barang masuk dan keluar sehingga pencatatan yang dilakukan untuk persediaan barang hanya dilakukan sederhana tanpa memperhatikan tanggal masuk dan keluar persediaan tersebut.Manajemen persediaan yang tidak baik dalam usaha mikro dan kecil ini bisa membuat perusahaan merugi secaraperlahan.Persediaan merupakan asset milik perusahaan yang cukup besar dibandingkan asset lancar lainnya.Pada perusahaan dagang, persediaan merupakan aspek penting yang harus dimiliki perusahaan, tanpa persediaan maka tidak ada aktivitas jual beli. Jika stok persediaan barang dagang berkurang akan berdampak pada terhambatnya penjualan barang dagang. Namun sebaliknya, apabila terdapat stok persediaan berlebih bisa berdampak pada bertumpuknya persediaan sehingga beresiko pada terjadinya kerusakan, kadaluarsa dan pada akhirnya tidak dapat dijual kembali kepada pelanggan.

Agar tidak terjadi masalah seperti itu, maka diperlukan sebuah pencatatan yang dapat mencatat seluruh transaksi terkait persediaan. Hal inilah yang mendorong untuk melakukan pengabdian kepada masyarakat mengenai Sosialisasi Pengelolaan Persediaan Barang dagang pada UMKM di Desa Suka Makmur Kecamatan Deli Tua Kabupaten Deli Serdang pada masa Pandemi Covid 19.

\section{B. Permasalahan Mitra}

Dari analisis situasi, permasaahan yang dimiliki oleh pelaku UMKM di Desa Suka Makmur adalah

1. Menurunnya Pendapatan pelaku usaha UMKM

2. Persediaan barang yang menumpuk

3. Persediaan barang yang rusak akibat terlalu lama menumpuk dan belum laku terjual 
GANDRUNG: Jurnal Pengabdian Kepada Masyarakat ISSN: 2721-6136 (Online)

\section{Solusi dan Target Luaran}

Berdasarkan permasalahan yang dialami oleh mitra maka tim pengusul memiliki solusi dengan mengadakan kegiatan sosialisasi atau pelatihan pemecahan masalah khususnya dalam hal pengelolaan persediaan barang dagang dengan mengacu pada langkah-langkah penyelesaian masalah. Sebelum kegiatan ini dilaksanakan maka penulis melakukan survey pendahuluan ke lokasi mitra untuk mendapatkan permasalahan yang dihadapi. Kemudian setelah didapatkan pokok permasalahan yang ada maka tim pengabdi megirimkan proposal pengabdian kepada masyarakat khususnya ke Desa Suka Makmur dengan menguraikan rencana kegiatan pengabdian. Kegiatan ini bertujuan untuk mencari solusi melalui pelatihan pengelolaan persediaan barang dagang.bagi UMK di Desa Suka Makmur.

\section{Metode}

Adapun pendekatan yang digunakan dalam rangka pengabdian kepada masyarakat ini adalah menggunakan metode Sosialiasi. Kegiatan pelatihan pengelolaan persediaan barang dagang bagi UMKM di Desa Suka Makmur ini telah dilaksanakan pada tanggal 1 sd 4 Juli 2021, dengan tentative kegiatan sebagai berikut:

Tabel 1. Jadwal Pelaksanaan

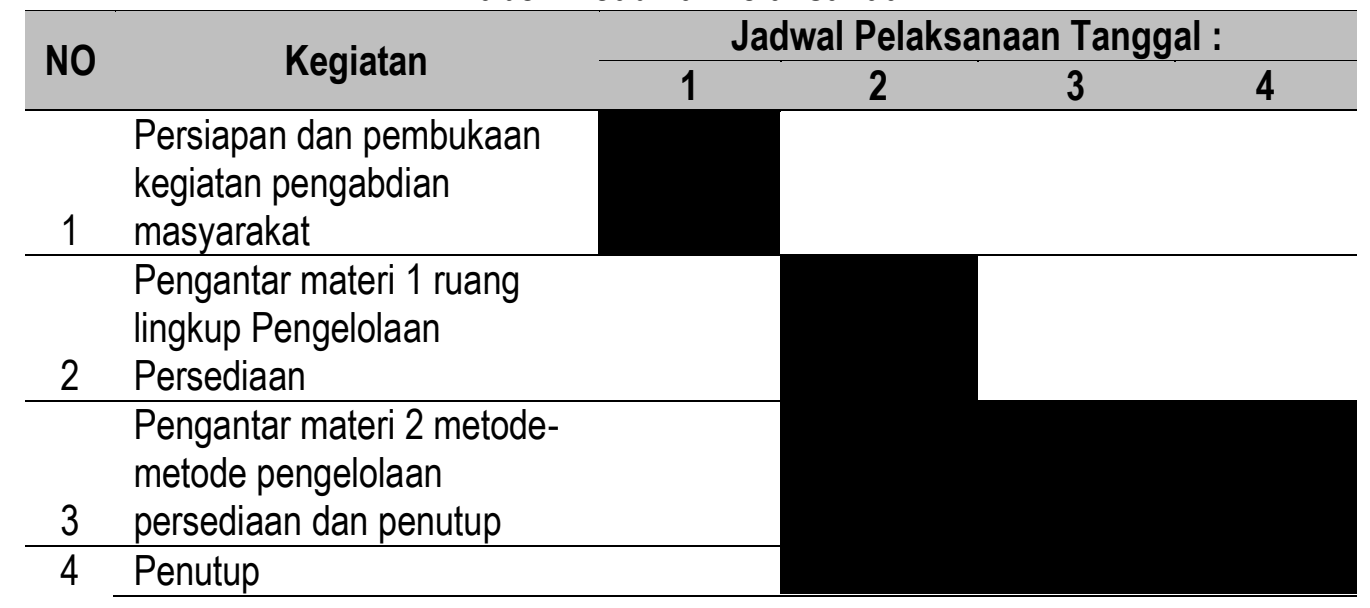

Adapun tempat kegiatan pengabdian masyarakat ini dilaksanakan di Aula Desa Suka Makmur Kecamatan Deli Tua 
GANDRUNG: Jurnal Pengabdian Kepada Masyarakat ISSN: 2721-6136 (Online)

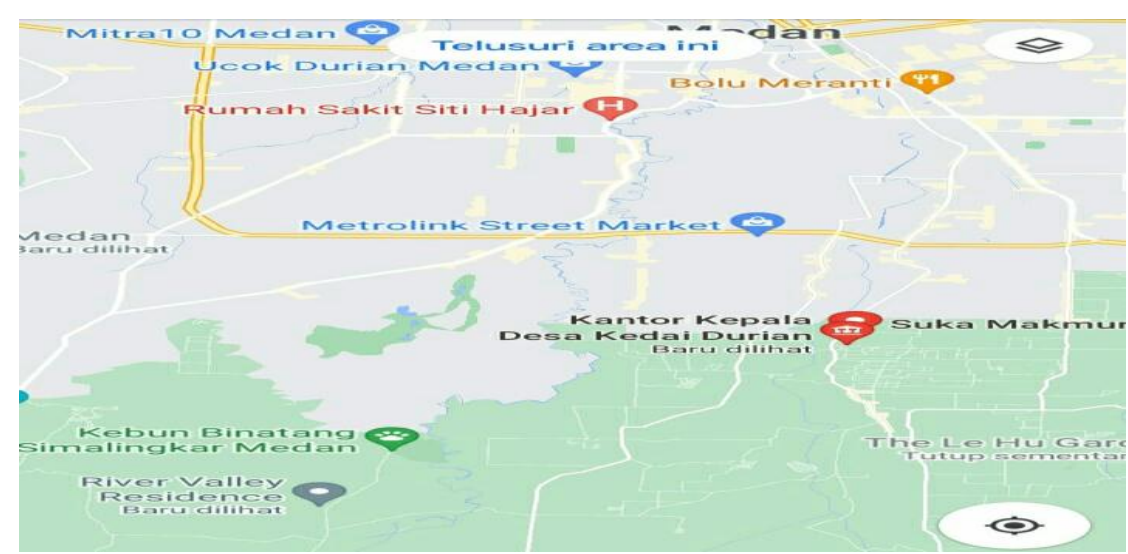

Gambar 1. Lokasi Pengabdian Masyarakat

Tabel 2.Susunan TIM Pengabdian

\begin{tabular}{|c|c|c|c|}
\hline No & Peran dalam Tim & Tanggung jawab dalam Tim & Dosen/Mahasiswa \\
\hline 1 & Drs. Harkim, M.Si & Penanggung Jawab dan Ketua Pengabdi & Dosen \\
\hline 2 & $\begin{array}{l}\text { Rejekia V. } \\
\text { Simanungkalit, SE, } \\
\text { MM }\end{array}$ & Anggota pengabdian & Dosen \\
\hline 3 & $\begin{array}{l}\text { Maya Andriani, S.Pd, } \\
\text { MM }\end{array}$ & Anggota pengabdian & Dosen \\
\hline 4 & $\begin{array}{l}\text { DR. Bambang } \\
\text { Sugiharto }\end{array}$ & Anggota pengabdian & Dosen \\
\hline
\end{tabular}

Table 3. Tugas Pokok serta Peran setiap TIM Pengabdian

\begin{tabular}{lllll}
\hline No & keterangan & \multicolumn{1}{c}{$\begin{array}{c}\text { Program } \\
\text { Hari-1, Kamis 1 Juli 2021 }\end{array}$} & Waktu & Pemateri \\
& & \multicolumn{1}{c}{ 08.30-09.00 } & Suyatno \\
$\mathbf{1}$ & Pembukaan & kata sambutan bapak kepala desa & $09.00-09.30$ & Harkim \\
$\mathbf{2}$ & Pembukaan & Ketua sambutan Tim pengabdian & $09.30-12.30$ & Rejekia \\
\hline
\end{tabular}

Hari-2, Jumat 2 JUli 2021

\begin{tabular}{|c|c|c|c|c|}
\hline No & keterangan & Program & Waktu & Pemateri \\
\hline 1 & Materi & Metode pemilihan persediaan & $08.30-12.00$ & Maya \\
\hline 2 & Materi & Studi kasus persediaan & $14.00-16.00$ & Bambang \\
\hline
\end{tabular}

Hari-3, 3 Juli 2021

\begin{tabular}{lllll}
\hline No & keterangan & \multicolumn{1}{c}{$\begin{array}{c}\text { Program } \\
\text { Hari-1, Kamis 1 Juli 2021 }\end{array}$} & Waktu & Pemateri \\
& & & & \\
$\mathbf{1}$ & Materi & Perkembangan UMKM & $08.30-12.00$ & Harkim \\
$\mathbf{2}$ & Materi & UMKM menginternasional & $14.00-16.00$ & Bambang \\
\hline
\end{tabular}

Hari-4, 4 Juli 2021

\begin{tabular}{|c|c|c|c|c|}
\hline No & keterangan & Program & Waktu & Pemateri \\
\hline
\end{tabular}


GANDRUNG: Jurnal Pengabdian Kepada Masyarakat ISSN: 2721-6136 (Online)

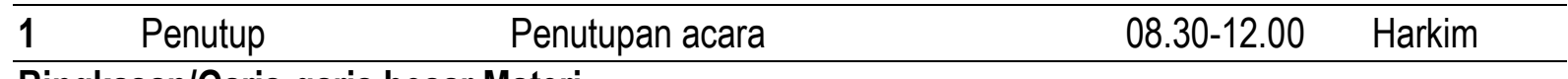

Ringkasan/Garis-garis besar Materi

\section{Usaha Mikro, Kecil dan Menengah (UMKM)}

Usaha Mikro Kecil dan Menengah (UMKM) saat ini merupakan usaha yang masih dapat bertahan di tengah badai krisis moneter yang berkepanjangan. UMKM berperan strategis dalam pembangunan perekonomian nasional dan mengalami perkembangan tiap tahun yang cukup pesat. Untukitu, pemerintah berupaya dengan keras untuk membina usaha kecil dan menengah guna menjadikannya sebagai penyumbang devisa bagi Negara.

Menurut Undang-Undang Republik Indonesia Nomor 9 Tahun 1995 tentang Usaha Kecil pasal 1 ayat 1 menyatakan bahwa usaha kecil adalah kegiatan ekonomi rakyat yang berskala kecil dan memenuhi kriteria kekayaan bersih atau hasil penjualan tahunan serta kepemilikan sebagaimana diatur dalam undang- undang. Kriteria usaha kecil dalam undang-undang tersebut tercantum pada pasal 5 ayat 1 yaitu dengan ketentuan sebagai berikut:

1. Memiliki kekayaan bersih paling banyak $\mathrm{Rp} 200.000 .000,00$ (dua ratus juta rupiah) tidak termasuk tanah dan bangunan tempatusaha.

2. Memiliki hasil penjualan tahunan paling banyak Rp 1.000.000.000,00 (satu miliar rupiah).

3. Milik Warga Negara Indonesia

4. Berdiri sendiri, bukan anak perusahaan atau cabang perusahaan yang dimiliki, dikuasai, atau berafiliasi baik langsung maupun tidak langsung dengan usaha menengah atau usaha besar.

5. Berbentuk usaha orang perorangan, badan usaha yang tidak berbadan hukum, badan usaha yang berbadan hukum, termasuk koperasi.

\section{Persediaan Barang Dagang}

Menurut (Ristono, 2009) mengartikan persediaan adalah barang-barang yang disimpan untuk digunakan atau dijual pada masa yang akan datang. Sedangkan persediaan adalah barang yang dimiliki untuk dijual kembali atau digunakan untuk memproduksi barang-barang yang akan dijual (Baridwan, 2015).

\section{Jenis - Jenis Persediaan}

Menurut (Santoso, 2010) menyatakan pengelompokan persediaan didasarkan pada jenis perusahaannya. Bagi perusahaan dagang (merchandise enterprise) dimana persediaan merupakan 
GANDRUNG: Jurnal Pengabdian Kepada Masyarakat ISSN: 2721-6136 (Online)

barang yang langsung diperdagangkan tanpa mengalami proses lanjutan, maka persediaan disebut sebagai persediaan barang dagangan (merchandise inventory). Sedangkan pada perusahaan industri dimana persediaan bahan baku memerlukan proses lebih lanjut agar siap dijual dalam bentuk barang jadi (finishes goods), maka persediaan dikelompokkan menjadi bahan baku, barang dalam proses, barang jadi, dan bahan pembantu.

\section{Sistem Pencatatan Persediaan}

1. Sistem pencatatanperpetual

Dalam sistem perpetual, catatan mengenai harga pokok dari masing-masing barang dagangan yang dibeli maupun yang dijual diselenggarakan secara terperinci. Sistem pencatatan ini akan secara terus menerus menunjukkan berapa besarnya saldo persediaan barang dagangan yang ada di gudang untuk masing-masing jenis persediaan. Dengan sistem pencatatan perpetual, harga pokok dari barang yang dijual ditentukan setiap kali penjualan terjadi (Hery, 2013).

2. Sistem pencatatan periodik

Menurut (Rudianto, 2012) menjelaskan pencatatan fisik/periodik (phisical/periodic inventory) merupakan pencatatan persediaan dimana:

a. Mutasi persediaan tidak menggunakan buku besar (inventory) melainkan memakai

b. perkiraan purchases, purchases return, sales, sales return dansebagainya

c. Tidak memakai kartu persediaan

d. Kalkulasi biaya persediaan dengan menetapkan persediaan akhir telebih dahulu melalui perhitungan secara fisik selanjutnya dihitung cost of good sold.

\section{Metode Penilaian Persediaan}

Menurut (Santoso, 2010) ada beberapa macam metode penilaian persediaan yang umumdigunakan, yaitu :

1. Last-in, First-out(LIFO)

Metode ini didasarkan pada asumsi bahwa himpunan harga pokok yang terakhir akan dibebankan sebagai harga pokok barang yang dijual,dengandemikian niai persediaan yang akan disajikan pada neraca merupakan himpunan biaya (cost) yang berasal dari pembelian-pembelian yangpertama.

2. First-in, First-out(FIFO)

Berdasarkan asumsi ini harga pokok yang harus dibebankan sebagai harga pokok barang yang dijual adalah himpunan harga pokok yang berasal dari pembelian-pembelian yang paling awal, 
dengan demikian nilai persediaan akan berasal dari himpunan harga pokok yang berasal dari pembelian-pembelian terakhir.

3. Average Cost (BiayaRata-Rata)

Metode ini didasarkan pada suatu asumsi bahwa nilai persediaan akhir merupakan himpunan harga pokok rata-rata dari persediaan itu sendiri, sehingga baik nilai persediaan maupun harga pokok barang yang dijual selalu akan mempunyai bagian yang sama terhadap harga pokok yang terhimpun dari persediaan tersebut. Dalam sistem persediaan terus - menerus, asumsi ini dikenal dengan istilah metode rata - rata bergerak (moving average method) karena harga pokok per unit akan selalu berubah setiap terjadi mutasi.

FIFO (First-In, First-Out) adalah metode untuk menentukan harga pokok penjualan dengan cara mengasumsikan bahwa produk yang sudah terjual merupakan produk terlama dalam inventaris. Biaya yang dikeluarkan untuk produk terlama itulah yang digunakan dalam perhitungan. Singkatnya, metode FIFO akan menghapus produk paling awal yang masuk dari akun persediaan setiap terjadi penjualan. Misalnya, Anda menjalankan bisnis penjualan roti, maka roti yang terlebih dahulu dijual yaitu roti yang pertama kali masuk ketoko anda. Perhitungan biaya dari roti yang terjual pertama itulah yang dijadikan sebagai biaya pokok penjualan.

FIFO cocok diterapkan di perusahaan yang memproduksi makanan karena penjualan produk terlama akan menjadikan persediaan selalu fresh. Makanan yang telah diproduksi tapi penyimpanannya tumpang tindih akan membuat perusahaan Anda mengalami kesulitan saat proses distribusi. Produk terlama yang tidak segera dijual akan mengalami penurunan kualitas dan hal tersebut menyebabkan kerugian bagi perusahaan anda.

Produk makanan juga masuk dalam kategori ini. Akan tetapi, perusahaan seperti warung kelontong, minimarket, dan supermarket memiliki produk yang lebih beragam jenisnya dengan batasan kadaluarsa yang berbeda pula. Maka dari itu, metode FIFO sejalan dengan konsep penjualan mereka. Jika Anda merupakan pengusaha di bidang ini, Anda pasti akan meletakkan produk yang terlebih dahulu masuk ke gudang atau ke catatan inventaris pada bagian paling depan rak display agar produk tersebut diambil lebih dulu oleh pembeli.

Rata-rata, semua staf yang bertugas mendisplay produk akan membongkar sisa produk di rak, memasukkan produk baru di bagian paling belakang, baru kemudian memasukkan kembali produk terlama di bagian depan. Dengan cara seperti itu, persediaan akhir di gudang penyimpanan akan tetap tinggi dan cenderung stabil tapi pengeluaran tetap bergantung pada produk yang tersedia di rak display. 
GANDRUNG: Jurnal Pengabdian Kepada Masyarakat ISSN: 2721-6136 (Online)

\section{Hasil dan Diskusi}

Kegiatan pengabdian ini telah teerlaksana dengan baik sesuai dengan yang direncanakan. Kegiatan pengabdian dilakukan dengan memberikan pelatihan pengelolaan persediaan yang dihadiri oleh pelaku UMKM di Desa Suka Makmur. Kegiatan pengabdian masyarakat ini dilaksanakan pada $1 \mathrm{sd}$ 2 Juli 2021 di Aula Desa Suka Makmur Kecamatan Deli Tua .kegiatan pengabdian ini diawali dengan kata sambutan oleh Bapak kepala Desa Suka Makmur, kemudian dilanjutkan dengan kata sambutan dari ketua pelaksanaan pengabdian masyarakat bapak Harkim Simamora, M.Si. setelah kata sambutan berakhir kemudian dilanjutkan dengan kegiatan sosialisasi/pelatihan oleh tim pengabdi terdiri dari Rejekia Vaizal Simanungkalit, SE, MM, Maya Andriani, S.Pd, MM, dan DR. Bambang Sugiharto.

Adapun materi pelatihan/sosialisasi yang disampaikan meliputi ruang lingkup pengelolaan persediaan, serta metode-metode dalam pencatatan persediaan. Materi-materi tersebut disampaikan secara bergantian oleh tim pengabdi.

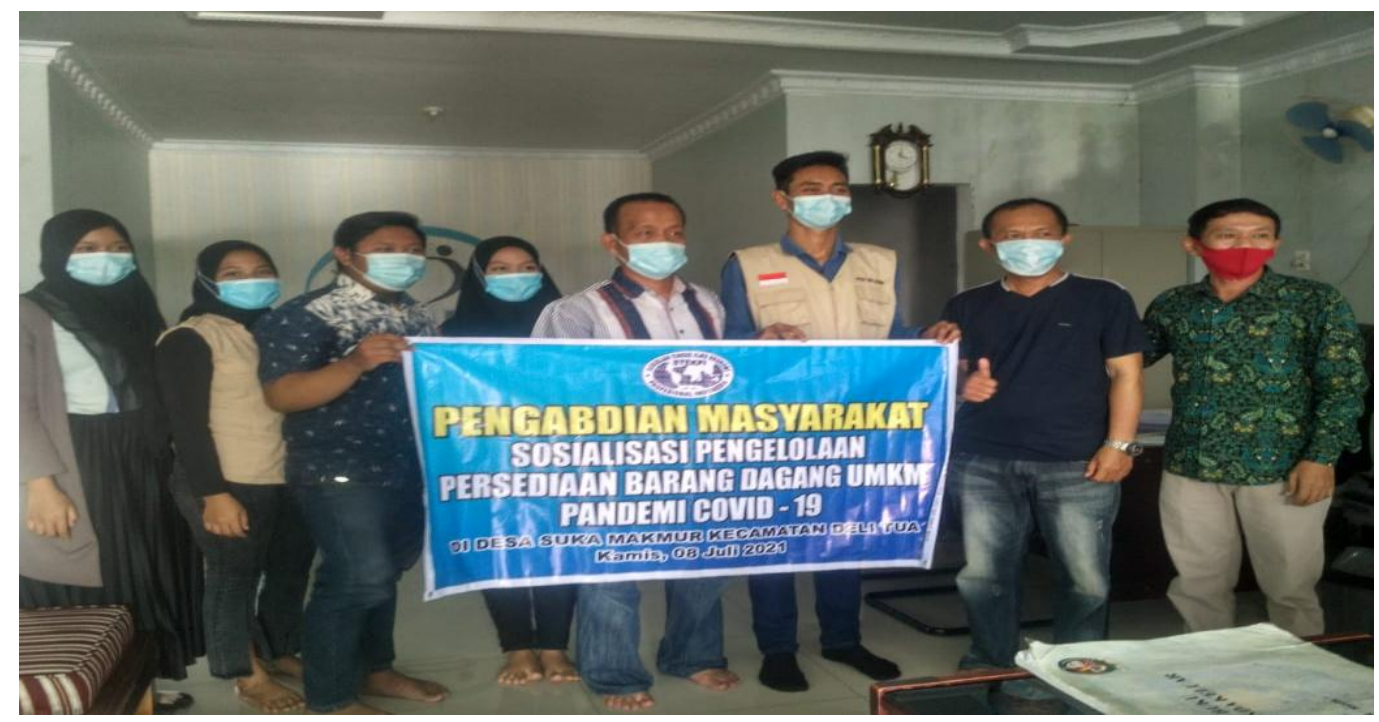

Gambar 2. Pelaksanaan Pengabdian Masyarakat ( Tim dan Peserta Pelatihan ) 
GANDRUNG: Jurnal Pengabdian Kepada Masyarakat ISSN: 2721-6136 (Online)

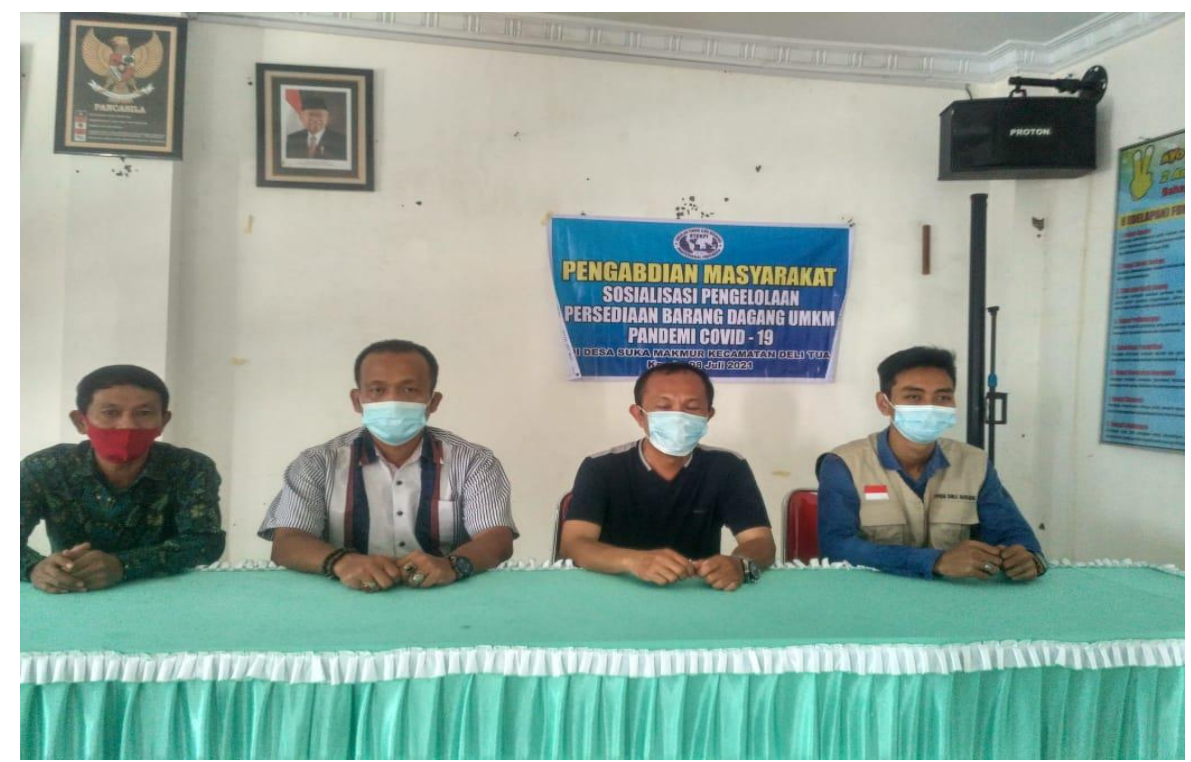

Gambar 3. Pembukaan Pengabdian Masyarakat

Hasil dari kegiatan pengabdian ini tim menemukan beberapa hal diantaranya terjadinya penurunan pendapatan akibat barang tidak terjual karna factor pandemic, stok barang digudang menumpuk, Karena terlalu lama disimpan digudang mengakibatkan stok barang rusak dan masa kadaluarsa habis sehingga harus dibuang dan menjadi sumber kerugian bagi para pelaku usaha.

Pada pelatihan ini pelaku UMKM diberikan wawasan dan keterampilan berupa pengelolaan persediaan yang baik dan tepat sesuai dengan situasi yang memang tidak bisa diprediksi akibat pandemic. Penggunaan metode yang tepat dalam pencatatan dan penilaian persediaan juga menjadi hal penting yang disampaikan mengingat dari hasil diskusi para pelaku UMKM belum mengetahui apalagi menggunakan metode-metode dimaksud.

Berdasarkan hasil dari pengabdian para pelaku UMKM di Desa suka Makmur mendapatkan tambahan ilmu berupaya pengelolaan persedian yang baik dan benar khususnya dimasa pandemic, dan para peserta juga berharap agar kiranya kegiatan yang sama akan tetap berlanjut dilaksanakan dengan topic-topik yang berbeda, mengingat sangat minimnya pengetahuan mereka dibidang teori.

\section{Kesimpulan}

Berdasarkan hasil isian angket dapat disimpulkan bahwa (1) Kegiatan Pengabdian Masyarakat ini berhasil, dapat meningkatkan pemahaman para pelaku usaha khususnya UMKM yang ada di Desa Suka Makmur Kecamatan Deli Tua dalam mengelola persediaan mereka pada masa pandemi, dan memberikan pengetahuan dalam pengelolaan persediaan agar optimal sehingga tidak ada lagi persediaan yang rusak akibat terlalu lama menumpuk di gudang, sehingga akan menyebabkan kerugian 
GANDRUNG: Jurnal Pengabdian Kepada Masyarakat ISSN: 2721-6136 (Online)

bagi pelaku usaha

\section{Rekomendasi}

Adapun rekomendasi yang diberikan oleh peserta pelatihan pada PKM ini adalah agar kegiatan pelatihan seperti ini tetap diberikan secara berkelanjutan kepada para pelaku UMKM, mengingat keterbatasan pemahaman mereka khususnya dibidang teori, dengan harapan agar mereka semakin memahami bagaimna pengelolaan terhadap persediaan dan meminimalisir kerugian akibat stok barang yang berlebih dan belum laku dijual.

\section{Daftar Referensi}

Baridwan, Z. (2015). Sistem Informasi Akuntansi. Cetakan Kesembilan. Yogyakarta: BPFE.

Hery. (2013). Akuntansi Keuangan Menengah 1 Edisi 1 Cetakan Pertama. Jakarta: PT. Bumi Aksara.

Istiyanto, R. I. A. K. R. K. B. (2017). Perbaikan Pengelolaan Umkm Guna Pengembangan Usaha Mikro. Jurnal Pengabdian Dan Pemberdayaan Masyarakat, 1(1), 30-37.

Ling, A. (2013). Pada Usaha Mikro Kecil Menengah (Studi Deskriptif Pada Rumah Makan Palem Asri Surabaya). Agora, 1(1), 1-8.

Puspitosari, L. L. I. (2020). Analisis Manajemen Persediaan Pada Usaha Mikro, Kecil, Dan Menengah (UMKM) Jazid Bastomi Batik Di Purworejo. Jurnal JESKaP, 4(1), 55-66.

Ristono, A. (2009). Manajemen Persediaan. Edisi 1. Yogyakarta: Graha Ilmu.

Rudianto. (2012). Pengantar Akuntansi Konsep\& Teknik Penyusunan Laporan Keuangan. Jakarta: Erlangga.

Santoso, I. (2010). Akuntansi Keuangan Menengah. Bandung: PT. Rafika Aditama. Bandung. 